\title{
Auditor Perceptions Of SAS 99: Do Two Expectation Gaps Still Exist?
}

Linda B. Specht, (E-mail: 1specht@trinity.edu), Trinity University

Petrea Sandlin, (E-mail: psandlin@trinity.edu), Trinity University

\begin{abstract}
In 1988, the Auditing Standards Board released nine standards intended to narrow the previously identified "expectation gap"- a gap between the expectations of financial statement users and certified public accountants ("Expectation Gap I"). A 1992 study of auditor perceptions of two of those standards dealing with errors, irregularities, and illegal acts of clients, revealed that there existed a second expectation gap, one between the standard setters and practicing CPAs ("Expectation Gap II"). Since then, the ASB has released two successor statements intended to address the issue of auditors' responsibility to consider fraud in a financial statement audit. This study examines auditor perceptions of the more recent pronouncement and reveals general skepticism among respondents regarding its effectiveness in promoting Congressional and public confidence in the auditing profession; i.e., little confidence that it will serve to reduce Expectation Gap I. It also reveals the continued existence of Expectation Gap II.
\end{abstract}

\section{Introduction}

In August 2000, the Panel on Audit Effectiveness (referred to hereafter as "the Panel") issued its "Report and Recommendations" regarding financial statement audits [the Panel (2000)]. The Panel had been given its mandate in 1998 by the Public Oversight Board (POB) ${ }^{1}$ in response to the Securities and Exchange Commission's (SEC) concerns over the effectiveness of financial statement audits of publicly held companies and the reliability of financial statements. Specifically, the Panel reviewed and evaluated "the way independent audits are performed and assessed the effects of recent trends in auditing on the public interest" [the Panel (2000)]. On January 20, 2002, on the heels of the Enron collapse and the SEC's renewed scrutiny of the accounting profession, the POB announced that it would terminate its existence. Meanwhile, the auditing profession, through efforts of the American Institute of CPAs (AICPA), had begun its response to the Panel's report by launching a number of projects, including the formation of various task forces and the issuance of several new standards in exposure draft form by the Auditing Standards Board (ASB). One of the exposure drafts specifically addressed the auditor's responsibility for considering fraud in a financial statement audit.

This study was begun shortly after the issuance of the ASB's Exposure Draft, "Proposed Statement on Auditing Standards: Consideration of Fraud in a Financial Statement Audit" [ASB (Feb. 2002)] (the "Proposed Fraud Statement"). The objectives of this study are to determine (1) whether auditors believe the implementation of the Proposed Fraud Statement will reduce the much publicized expectation gap between public expectations and auditors' perceptions of their responsibilities, and (2) whether there is continuing evidence of a second previously noted (but less publicized) expectation gap, one between the ASB and the CPA practitioner. Shortly after the data gathering phase of the study was completed, the Proposed Fraud Statement was adopted as an authoritative pronouncement of the ASB.

\footnotetext{
1 "The Public Oversight Board (POB) was an independent, private-sector body that monitored and reported on the self-regulatory programs and activities of the SEC Practice Section (SECPS) of the Division for CPA Firms of the American Institute of Certified Public Accountants (AICPA). The POB appointed the Panel in October 1998 at the request of Chairman Arthur Levitt of the Securities and Exchange Commission (SEC)." [The Panel (2000)].
} 


\section{Background}

In 1988, the ASB issued a number of pronouncements that have been referred to as the Expectation Gap standards [ASB (1988)]. The intent of these standards was to reduce the gap between public expectations and the perceptions of auditors with respect to auditors' roles and responsibilities in conducting financial statement audits. The Expectation Gap standards were intended to (1) address public concerns regarding detection of errors, irregularities and illegal acts, (2) assist auditors in planning more effective audits, (3) improve external auditor communications, and (4) improve internal communications [Guy and Sullivan (1988)]. For the purposes of the current study, the breach between public expectations and auditors' perceptions of their responsibilities will be referred to as "Expectation Gap I."

A study published in 1992, which examined auditors' perceptions of the effectiveness of the Expectation Gap standards, found that a second type of expectation gap existed, a gap between what the standards were intended to accomplish and auditor perceptions of what the statements would accomplish [Specht and Waldron (1992)]. For the purposes of the current study, this gap between the expectations of the auditing standard setters and the expectations of the practicing auditors will be referred to as "Expectation Gap II."

In 1997, Statement on Auditing Standards No. 82 ("SAS 82") replaced one of the Expectation Gap standards. It was intended to provide more explicit guidance for the auditor's consideration of fraud in a financial statement audit [ASB (1997)]. Nonetheless, concerns with earnings management by publicly held companies [Levitt (1998)] and the incidence of fraud [COSO (1999)] served to increase scrutiny of the external auditor's role during the late $20^{\text {th }}$ century. The Panel identified a number of factors that greatly influenced the business environment in which external auditors operated, including the increasing internationalization of the economy, the increasing use of technology by clients, and the increase in consulting revenues of CPA firms (raising questions of independence). Although the Panel found that "both the profession and the quality of its audits [were] fundamentally sound" [The Panel (2000)], its recommendations were numerous.

The AICPA and ASB initiatives in response to the Panel's recommendations are the most comprehensive of the past decade and include the following: reconsideration of the auditor's responsibility for detection of fraud, the audit risk model, the linkage of audit risk assessments with audit evidence, issues of auditor independence, leadership and practice of audit firms, and governance of the auditing profession (including peer review and disciplinary processes). Several of these initiatives have resulted in the issuance of new auditing standards. In February 2002, the ASB issued the Proposed Fraud Statement. Later that year, it was finalized as Statement on Auditing Standards No. 99 (the "Fraud Statement") and it replaced SAS 82.

As the ASB's projects began to result in the issuance of exposure drafts and new auditing standards, public inquiries involving the accounting policies of Enron and Global Crossing [Barboza (2002)], Adelphia [Norris (2002)], Halliburton [Berenson (2002)], Coca-Cola [Foust (2002)], Xerox [Deutsch (2002)], WorldCom [Romero and Berenson (2002), Romero and Norris (2002)] and a number of other companies have raised new questions as to the soundness of the audit process. Although the Fraud Statement was issued in the wake of both the Enron and WorldCom debacles, it is the culmination of one of the long-term projects that had been launched following the Panel's report. The Fraud Statement contains a number of significant changes from the guidance offered by its immediate predecessor, SAS 82. In fact, the Exposure Draft Summary lists eleven significant areas in which the adoption of the Fraud Statement affects current practice.

\section{Objectives of this Study}

This study's primary objective is to determine whether the expectation gap (Expectation Gap II) between the ASB and the practicing CPAs who must implement its pronouncements continues to exist. Although the practices auditors follow have been heavily scrutinized during the past decade, particularly regarding issues of independence and detection of client fraud, there has been little inquiry into the differing perceptions of the ASB and auditors as to the effectiveness of the current pronouncements. Recent research has been largely descriptive of the standard-setting process in the U.S. and abroad [What's (1994); Legislation (1995); The Future (1995); Parker 
(1995); Luscombe (1996); Xioa, Zhang, \& Xie (2000); Xinhua (2001)]. Other studies have criticized the standardsetting process [McEnroe (1994)], or have described efforts to enhance independence [Goldwasser (2001)] and curtail client practices such as earnings management [Jackson and Pitman (2001)]. There is no evidence in the literature that efforts have been made to address or explain the continuing possibility of the expectation gap between standard setters, themselves, and practicing CPAs. The primary purpose of this study is to examine this issue.

A secondary objective of this study is to examine auditors' perceptions as to whether the Fraud Statement will promote public confidence in the auditing profession, and thereby lessen Expectation Gap I between public expectations and auditors perceptions of their responsibilities. Other studies have been descriptive of efforts in the U.S. [Giacomino (1994)] and abroad [Hopkins (1997)] to bridge this recognized expectation gap. Several lines of inquiry have focused on the expectations of stakeholders in the U.K. [Dewing and Russell (2001)], the doubts of British respondents regarding proposed efforts to reduce the expectation gap [Manson and Zaman (1999)] and the mixed beliefs of U.K. auditors regarding the efficacy of the British standard on fraud in reducing the expectation gap [Fraud SAS (1995)]. This study provides evidence as to auditors' current perceptions on whether they think the Fraud Statement will promote public (and Congressional) confidence in the auditing profession.

\section{Research Methodology}

A mailed questionnaire was used to elicit the responses of managing partners of CPA firms randomly chosen from among the AICPA's SEC Practice Section membership. The questionnaire included (1) demographic questions and (2) perception questions related to the appropriateness and efficacy of the Proposed Fraud Statement. The earlier study that identified the existence of Expectation Gap II [Specht and Waldron (1992)] examined auditor perceptions of standards that addressed client errors, irregularities, and illegal acts; therefore, the Proposed Fraud Statement is used in this study in order to maintain consistency of subject matter. As previously mentioned, the earlier standard addressing client errors and irregularities was replaced by SAS 82, which would then be superseded by the Proposed Fraud Statement.

Demographic questions included inquiries as to whether the respondent had (1) read the Panel's report, (2) read the Proposed Fraud Statement, (3) provided comment to the ASB in response to the Proposed Fraud Statement, and (4) been subject to the filing of a lawsuit or a regulatory or disciplinary proceeding within the past five years as the result of a financial statement audit. Other questions asked the respondent to estimate the proportion of the firm's (1) audit engagements to the firm's practice (in chargeable hours), (2) clients that are publicly held, (3) nonpublic clients who have audit committees, (4) engagements that give rise to audit team discussions regarding the possibility of fraud, and (5) clients that evidence a risk of management override of internal controls. A final demographic question inquired as to the proportion of auditing exposure drafts read by the respondent.

\section{Results}

\section{The Influence of Demographics}

Respondents were asked four demographic questions that sought to measure their familiarity with the Panel's report and with the Proposed Fraud Statement, and their experience with legal and regulatory proceedings. Six additional demographic questions were asked regarding the nature of the respondents' practice. Their responses are summarized in Tables 1A and 1B, shown below.

Of interest was the extent to which the respondents' familiarity with the Panel's report and the Fraud Statement and their experience with legal and regulatory proceedings (the independent variables in the statistical analysis that was performed) might influence their perceptions about the appropriateness of the proposed changes (the dependent variables). Canonical correlation analysis was used to determine whether the two sets of variables were independent of one another, and if they were not, to determine the magnitude of the relationships that exist between the two sets. 


\begin{tabular}{|c|c|c|}
\hline $\begin{array}{c}\text { Table 1A--Familiarity With Pronouncements And Experience With Legal } \\
\text { And Regulatory Proceedings }\end{array}$ & $\begin{array}{c}\text { \% Who } \\
\text { Answered } \\
\text { "Yes" }\end{array}$ & $\begin{array}{c}\text { \% Who } \\
\text { Answered } \\
\text { "No" }\end{array}$ \\
\hline $\begin{array}{l}\text { a. Have you read the "Report and Recommendations of the Panel on Audit Effectiveness } \\
\text { (August 31, 2000)"? }\end{array}$ & $68 \%$ & $32 \%$ \\
\hline b. Have you read the Proposed Statement? & $64 \%$ & $36 \%$ \\
\hline $\begin{array}{l}\text { c. Did you or your firm provide comment to the Auditing Standards Board in connection } \\
\text { with the exposure draft of the Proposed Statement? }\end{array}$ & $7 \%$ & $93 \%$ \\
\hline $\begin{array}{l}\text { d. Has your firm been subject to the filing of a lawsuit or a regulatory or disciplinary } \\
\text { proceeding within the past five years as the result of a financial statement audit? }\end{array}$ & $9 \%$ & $91 \%$ \\
\hline
\end{tabular}

\begin{tabular}{|c|c|c|c|c|c|}
\hline \multirow{2}{*}{$\begin{array}{l}\text { Table 1B Practice Demographics } \\
\text { Respondents were asked to estimate the } \\
\text { following: }\end{array}$} & \multicolumn{5}{|c|}{$\begin{array}{c}\text { \% of respondents whose practice demographics reflect } \\
\text { the indicated proportion for each variable }\end{array}$} \\
\hline & $\begin{array}{c}\text { Variable } \\
\text { estimate }= \\
0-20 \%\end{array}$ & $\begin{array}{c}\text { Variable } \\
\text { estimate= } \\
21-40 \%\end{array}$ & $\begin{array}{r}\text { Variable } \\
\text { estimate= } \\
41-60 \%\end{array}$ & $\begin{array}{c}\text { Variable } \\
\text { estimate= } \\
61-80 \%\end{array}$ & $\begin{array}{r}\text { Variable } \\
\text { estimate= } \\
\mathbf{8 1 - 1 0 0 \%}\end{array}$ \\
\hline $\begin{array}{l}\text { a. Audit engagements as a proportion of the firm's } \\
\text { practice (in chargeable hours) }\end{array}$ & $4 \%$ & $57 \%$ & $34 \%$ & $5 \%$ & $0 \%$ \\
\hline $\begin{array}{l}\text { b. Proportion of the firm's clients that are publicly } \\
\text { held }\end{array}$ & $91 \%$ & $5 \%$ & $2 \%$ & $2 \%$ & $0 \%$ \\
\hline $\begin{array}{l}\text { c. Proportion of the firm's non-public clients who } \\
\text { have audit committees }\end{array}$ & $82 \%$ & $14 \%$ & $4 \%$ & $0 \%$ & $0 \%$ \\
\hline $\begin{array}{l}\text { d. Proportion of the firm's audit engagements that } \\
\text { give rise to audit team discussions regarding the } \\
\text { possibility of fraud }\end{array}$ & $56 \%$ & $21 \%$ & $3 \%$ & $9 \%$ & $11 \%$ \\
\hline $\begin{array}{l}\text { e. Proportion of the firm's audit clients that } \\
\text { evidence a risk of management override of internal } \\
\text { controls }\end{array}$ & $52 \%$ & $20 \%$ & $17 \%$ & $2 \%$ & $9 \%$ \\
\hline $\begin{array}{l}\text { f. Proportion of auditing exposure drafts that you } \\
\text { read }\end{array}$ & $23 \%$ & $19 \%$ & $11 \%$ & $19 \%$ & $28 \%$ \\
\hline
\end{tabular}

The results of the canonical correlation analysis (Appendix) indicate that the set of independent (demographic) variables explained an insignificant percentage of the variance in respondent perceptions. The lack of statistical significance and the lack of redundancy indicate that auditor perceptions were not influenced in any meaningful way by the set of demographic variables.

\section{Auditor's Perceptions}

Perception questions explored the appropriateness of each of the eleven significant changes in practice required by the Proposed Fraud Statement and the perceived efficacy of the initiative in meeting its intended goals. Perception questions are illustrated in Tables 3 and 4 below [Specht and Sandlin (2003)].

Descriptive statistics resulting from the analysis of the questionnaire responses and a review of accompanying commentary from respondents [Specht and Sandlin (2003)] indicated that the auditors were in general agreement with the ASB's changes in auditing guidance and that they believed that the Fraud Statement is a valid effort to respond to the Panel's recommendations. Responses to the items in Table 3 ranged from a high of 93 percent agreement with the changes requiring audit team discussions of fraud (outlined in Item 1) to a low of 59 percent agreement with the new documentation requirements listed at Item 10. 


\begin{tabular}{|c|c|}
\hline Table 3 The Following Change Would Be Appropriate: & $\begin{array}{c}\text { \% who agreed or } \\
\text { strongly agreed }\end{array}$ \\
\hline $\begin{array}{l}\text { 1. The Proposed Statement requires audit team discussion of (1) "how and where" the particular } \\
\text { client's financial statements might be susceptible to material misstatement due to fraud, and (2) } \\
\text { the importance of maintaining professional skepticism throughout the engagement. }\end{array}$ & $93 \%$ \\
\hline $\begin{array}{l}\text { 2. The Proposed Statement requires expanded inquiries of management, audit committees, } \\
\text { internal auditors, and others regarding risk, allegations, or knowledge of fraud; programs, } \\
\text { controls, and monitoring; and communication of business practices and ethics. }\end{array}$ & $84 \%$ \\
\hline $\begin{array}{l}\text { 3. The Proposed Statement organizes risk factors into three areas: incentive/pressure, } \\
\text { opportunity, and attitude/rationalization. }\end{array}$ & $85 \%$ \\
\hline $\begin{array}{l}\text { 4. The Proposed Statement describes the fraud risk assessment process as one that goes beyond } \\
\text { the consideration of risk factors to the identification of specific risks of material misstatement } \\
\text { due to fraud that should be considered in the auditor's response. }\end{array}$ & $60 \%$ \\
\hline $\begin{array}{l}\text { 5. The Proposed Statement offers expanded guidance on revenue recognition as a likely risk area } \\
\text { and provides possible responses to such an identified risk. }\end{array}$ & $88 \%$ \\
\hline $\begin{array}{l}\text { 6. The Proposed Statement requires the auditor to evaluate the client's programs and controls } \\
\text { that address the identified risks and to consider whether they mitigate the risks. }\end{array}$ & $83 \%$ \\
\hline $\begin{array}{l}\text { 7. The Proposed Statement offers extensive examples of three types of auditor responses to } \\
\text { selected risks: overall responses; responses involving the nature, timing and extent of } \\
\text { procedures; and responses that address risks due to management override of controls. }\end{array}$ & $81 \%$ \\
\hline $\begin{array}{l}\text { 8. The Proposed Statement increases the emphasis on professional skepticism through its new } \\
\text { discussion requirements and focuses on the effect of professional skepticism on the "gathering } \\
\text { and evaluation of evidential matter when fraud risks are identified." }\end{array}$ & $83 \%$ \\
\hline $\begin{array}{l}\text { 9. The Proposed Statement provides examples of additional substantive tests in response to the } \\
\text { risk of management override of controls. }\end{array}$ & $85 \%$ \\
\hline $\begin{array}{l}\text { 10. The Proposed Statement requires expanded documentation of the auditor's consideration of } \\
\text { fraud, to include documentation of discussions, procedures, identification of risks and responses, } \\
\text { decisions to forego certain procedures, and the nature of communication with others about fraud. }\end{array}$ & $59 \%$ \\
\hline $\begin{array}{l}\text { 11. The Proposed Statement incorporates guidance regarding the impact of technology on the } \\
\text { risk of fraud and the use of technology in designing audit procedures. }\end{array}$ & $85 \%$ \\
\hline
\end{tabular}

\begin{tabular}{||l|c||}
\hline \multicolumn{1}{|c|}{ Table 4 Adoption Of The Proposed Statement: } & $\begin{array}{c}\text { \% who agreed or } \\
\text { strongly agreed }\end{array}$ \\
\hline $\begin{array}{l}\text { 1. Would be an appropriate response to public concerns regarding the auditor's role in the } \\
\text { prevention or detection of fraud. }\end{array}$ & $59 \%$ \\
\hline $\begin{array}{l}\text { 2. Would be an appropriate response to the "Report and Recommendations of the Panel on Audit } \\
\text { Effectiveness". }\end{array}$ & $76 \%$ \\
\hline $\begin{array}{l}\text { 3. Would result in a substantial change in the auditor's performance, thereby improving the } \\
\text { likelihood that auditors will detect material misstatements due to fraud in a financial statement } \\
\text { audit. }\end{array}$ & $24 \%$ \\
\hline $\begin{array}{l}\text { 4. Would result in an increased focus on professional skepticism in the consideration of the risk } \\
\text { of fraud in a financial statement audit. }\end{array}$ & $67 \%$ \\
\hline 5. Would improve audit planning and performance. & $50 \%$ \\
\hline 6. Would promote Congressional and public confidence in the auditing profession. & $38 \%$ \\
\hline 7. Would reduce the likelihood of federal regulation of the auditing profession. & $28 \%$ \\
\hline 8. Would improve the quality of communications with clients. & $47 \%$ \\
\hline
\end{tabular}

The CPA practitioners' responses as to the effect they thought the Fraud Statement would have on Expectations Gaps I and II, however, were not optimistic. While the auditors indicated that they thought the Fraud Statement would be an appropriate response to public concerns and to the Panel's recommendations, a majority did not think that it "would result in a substantial change in audit performance, thereby improving the likelihood that auditors will detect material misstatements due to fraud in a financial statement audit" (Table 4, Item 3). Therefore, the results of this study echo the prior finding [Specht and Waldron (1992)] that a significant gap (Expectation Gap II) exists between what the ASB intends its auditing standards to accomplish and what auditors believe will be 
accomplished. Only 24 percent of the respondents agreed that the Fraud Statement would result in a substantial change in the auditor's performance, indicating that there is a still a wide gap between what the ASB hopes to accomplish and the effect that auditors think the Statement will have. Expectation Gap II, first identified following the issuance of the Expectation Gap standards in 1988, still exists.

Furthermore, the auditors' responses as to the effect they thought the Fraud Statement would have on Expectation Gap I, the breach between public expectations and auditors' perceptions, indicate little confidence that the gap will be narrowed. Only 38 percent of the respondents indicated that they thought the adoption of the Fraud Statement would promote Congressional and public confidence in the auditing profession (Table 4, Item 6), and even fewer, 28 percent of the respondents, thought that the adoption of the Fraud Statement would reduce the likelihood of federal regulation of the auditing profession (Table 4, Item 7).

\section{Summary}

These findings indicate that Expectation Gap II continues to flourish and that auditors have no confidence that Expectation Gap I will be reduced by the profession's efforts to implement the Fraud Statement. Since the study was initiated, the collapse of both Enron and WorldCom have resulted in a greater degree of Congressional and SEC regulation of the auditing profession. The days of a self-regulating profession are not completely over, but the degree of self-regulation has markedly decreased with respect to audits of publicly held clients. Nonetheless, the ASB will continue to issue auditing standards and the expectations of three groups - the standard setters, the CPA practitioners, and the users of the financial statements--must be considered and reconciled in order to properly serve the public interest.

\begin{tabular}{|c|c|c|c|c|c|c|}
\hline \multicolumn{7}{|c|}{ Appendix Table 1 Canonical Correlation Analysis } \\
\hline \multirow[b]{2}{*}{$\begin{array}{l}\text { Canonical } \\
\text { Function }\end{array}$} & \multirow[b]{2}{*}{$\begin{array}{r}\text { Canonical } \\
\text { Correlation } \\
\end{array}$} & \multicolumn{2}{|c|}{ Redundancy Indexes } & \multirow[b]{2}{*}{$\mathrm{R}^{2}$} & \multirow[b]{2}{*}{ F Statistic } & \multirow[b]{2}{*}{ Prob. } \\
\hline & & $\begin{array}{l}\text { Dependent } \\
\text { Variables. }\end{array}$ & $\begin{array}{l}\text { Independent } \\
\text { Variables }\end{array}$ & & & \\
\hline 1 & 0.836171 & 0.0491 & 0.0983 & 0.699182 & 0.93 & 0.707 \\
\hline 2 & 0.766981 & 0.0226 & 0.0684 & 0.588260 & 0.79 & 0.948 \\
\hline 3 & 0.697076 & 0.0169 & 0.0316 & 0.485914 & 0.69 & 0.990 \\
\hline 4 & 0.660702 & 0.0273 . & 0.0378 & 0.426527 & 0.62 & 0.997 \\
\hline 5 & 0.580948 & 0.0117 & 0.0282 & 0.337501 & 0.54 & 0.999 \\
\hline 6 & 0.573338 & 0.0196 & 0.0258 & 0.328716 & 0.49 & 0.999 \\
\hline 7 & 0.501021 & 0.0140 & 0.0268 & 0.251022 & 0.38 & 0.999 \\
\hline 8 & 0.382620 & 0.0093 & 0.0166 & 0.146398 & 0.27 & 1.000 \\
\hline 9 & 0.279588 & 0.0039 & 0.0081 & 0.078169 & 0.19 & 1.000 \\
\hline 10 & 0.188421 & 0.0013 . & 0.0037 & 0.035503 & 0.13 & 0.999 \\
\hline
\end{tabular}

Appendix Table 2 Multivariate Test Statistics

\begin{tabular}{lccc} 
Statistic & Value & $\begin{array}{c}\text { Approximate } \\
\text { F statistic }\end{array}$ & Prob. \\
\hline Wilks' lambda & & & \\
Pillai's Trace & 0.00906995 & 0.93 & 0.7078 \\
Hotelling-Lawley Trace & 3.38719074 & 0.94 & 0.6706 \\
Roy's Greatest Root & 7.10027494 & 0.91 & 0.7160 \\
& 2.32426816 & 4.28 & $<.0001$ \\
\hline
\end{tabular}




\section{(1) Level of Statistical Significance}

The level of significance of a canonical correlation that is generally considered to be the minimum for interpretation is the .05 level. Table 4 illustrates that the canonical correlations of each of the ten canonical functions are not statistically significant. In addition to separate tests of each canonical function, multivariate tests of all of the ten functions were also performed. The test statistics employed were Wilks' lambda, Pillai's criterion, Hotelling's trace, and Roy's greatest root. Table 5 reports these multivariate test statistics, and the first three indicate that the canonical functions, taken collectively, are not statistically significant. These criteria assess the differences across "dimensions" of the dependent variables. Roy's Greatest Root, which measures the differences on only the first canonical root among the dependent variables, indicates statistical significance. However, this measure is most appropriate when the dependent variables are strongly interrelated on a single dimension. The other three measures are more robust and are more able to deal with violations of normality assumptions of the functions.

\section{(2) Magnitude of the Canonical Relationships}

Although the canonical correlations of each of the ten functions can be deemed to be statistically insignificant, the size of the canonical correlations must also be considered. No generally accepted guidelines have been established regarding acceptable sizes for canonical correlations. Rather, the decision is usually made based on the contribution of the findings to better understand the research problem being studied.

\section{(3) Redundancy Measure of Shared Variance}

Redundancy indexes were also computed to measure the amount of variance in each set of variables explained by a linear composite of the other set of variables. These indexes are the proportions listed under Redundancy Indexes in Table 4. As can be seen, the redundancy indexes for both the dependent and independent variates are all low, indicating that the independent (demographic) variables explained an insignificant percentage of the variance in respondent perceptions. For example, the redundancy index of the dependent variables for the first function (.0983) indicates that only 9.83 percent of the variance in auditor perceptions is explained by the set of demographic variables.

\section{Bibliography}

1. Auditing Standards Board (“ASB”). (April 1988). "Statements on Auditing Standards" No. 53-61, various titles.

2. Auditing Standards Board (“ASB”). (February 1997). "Statement on Auditing Standards" No. 82, Consideration of Fraud in a Financial Statement Audit.

3. Auditing Standards Board (“ASB"). (May 4, 2001). "Exposure Draft", Proposed Statement on Auditing Standards, Generally Accepted Auditing Standards.

4. $\quad$ Auditing Standards Board (“ASB”). (June 27, 2001). "Exposure Draft”, Proposed Statement on Auditing Standards and Statement on Standards for Attestation Engagements, Audit Documentation.

5. Auditing Standards Board (“ASB”). (February 28, 2002). "Exposure Draft”, Proposed Statement on Auditing Standards: Consideration of Fraud in a Financial Statement Audit.

6. Auditing Standards Board ("ASB"). (October 2002). "Statement on Auditing Standards: Consideration of Fraud in a Financial Statement Audit".

7. Barboza, David and Simon Romero. "Enron Has Link to Global Crossing," The New York Times (May 20, 2002) Available at www.nytimes.com.

8. Berenson, Alex. "Halliburton and Inquiry by the S.E.C.", The New York Times (May 30, 2002) Available at www.nytimes.com.

9. "Cambodia Introduces New Accounting Standards," Xinhua_(August 29, 2001).

10. Committee of Sponsoring Organizations of the Treadway Commission ("COSO"). (1999). "Fraudulent Financial Reporting: 1987-1997, An Analysis of U. S. Public Companies”.

11. Deutsch, Claudia, H. "Xerox Revises Revenue Data, Tripling Error First Reported," The New York Times (June 29, 2002) Available at www.nytimes.com. 
12. Dewing, Ian and Peter Russell. "Bridging the expectations gap," Accountancy 128 (July 2001): 98.

13. Foust, Dean and David Henry. "Has Coke Been Playing Accounting Games?" BusinessWeek (May 13, 2002): 98-99.

14. "Fraud SAS won't bridge the gap," Accountancy 115 (March 1995): 15.

15. Giacomino, Don E. "Expanding the auditors' role to narrow the expectations gap," Business Forum 19 (Summer/Fall 1994): 31-36.

16. Glater, Jonathan D. "Audit Firms Are Set to Alter Some Practices," The New York Times (February 1, 2002) Available at www. Nytimes.com.

17. Goldwasser, Dan L. "The SEC's New Auditor Independence Standard," CPA Journal 71(April 2001) 1824.

18. Guy, Dan M. and Jerry D. Sullivan. "The Expectation Gap Auditing Standards," Journal of Accountancy (April 1988): 36-46.

19. Hopkins, Bob. (1997). "Perceptions of Audit Quality—A Survey Analysis". London: CIPFA Publications.

20. Jackson, Scott B. and Marshall K. Pitman. "Auditors and Earnings Management," CPA Journal 71 (July 2001): 39-45.

21. Jones, Russell A. (1977). "Self-Fulfilling Prophecies: Social, Psychological, and Physiological Effects of Expectations", John Wiley \& Sons.

22. "Legislation likely," Accountancy 115 (February 1995): 12.

23. Levitt, Arthur. "The Numbers Game" (NYU Center for Law and Business, September 28, 1998).

24. Luscombe, Nelson. “A Delicate Balance,” CA Magazine (129 (December 1996): 3.

25. Manson, Stuart and Mahbub Zaman. "Lobbying the Auditing Practices Board: analysis of responses to the expanded audit report," Accounting Forum 23 (March 1999): 11-35.

26. McEnroe, John E. "An examination of voting behavior of the ASB," Journal of Accounting, Auditing \& Finance 9 (Winter 1994): 117-142.

27. Norris, Floyd. “Adelphia May Redo Results to Show \$2.3 Billion Debt,” The New York Times (April 17, 2002) Available at www.nytimes.com.

28. Parker, Collin. "The Urgent Issues Group - a new force in standard-setting," Australian Accountant 65 (July 1995): 17-20.

29. Romero, Simon and Alex Berenson. "WorldCom Says It Hid Expenses, Inflating Cash Flow \$3.8 Billion," The New York Times (June 26, 2002) Available at www.nytimes.com.

30. Romero, Simon and Floyd Norris. "New Bookkeeping Problems Are Disclosed by WorldCom," The New York Times (July 2, 2002) Available at www.nytimes.com.

31. Specht, Linda B. and Darryl G. Waldron. "Auditor Perceptions of Statements on Auditing Standards 53 and 54: A Study of Demographics and Perceptions of Efficacy," Journal of Applied Business Research (Spring 1992): 87-93.

32. Specht, Linda B. and Petrea K. Sandlin, "SECPS Member Perceptions of the Exposure Draft On Fraud: The ASB Is On The Right Track, But Will It Make A Difference?" The CPA Journal 73 (February 2003):10-13.

33. "The future of auditing standard setting," The CPA Journal 65 (February 1995): 12.

34. The Panel on Audit Effectiveness. (2000) Report and Recommendations. Available at www.aicpa.org.

35. "What's going on," CA Magazine 127 (September 1994): 60-65.

36. Xiao, Jason Zezhong, Yikuan Zhang, and Zhihua Xie, "The Making of Independent Auditing Standards in China," Accounting Horizons 14 (March 2000): 69-90. 